\title{
Liberal Warfare: A Crusade Twice Removed
}

\author{
David A. Hughes \\ Oxford Brookes University
}

\begin{abstract}
Since the 1990s, liberal warfare has attracted a good deal of debate and commentary, virtually all of which has been framed in the secular language of rights, sovereignty, power, and legitimacy. This article, in contrast, makes religion its central analytic category. Treating liberalism as a political religion, it argues that, insofar as liberal wars are fought primarily to uphold "universal" Western values, their motivation has something in common with medieval crusades. But, because that universalist ideal is vitiated by the self-interest of states, liberal wars in fact bear closer resemblance to anachronistic attempts to revive the crusading ideal in the late Middle Ages. Thus, they represent a distant, secularized echo of a pale imitation of the Crusades - or "a crusade twice removed."
\end{abstract}

\begin{abstract}
Liberal universalists are right that some values are universal. They are wrong in identifying universal values with their own particular ideals. Human rights are not a charter giving universal authority to liberal values. They are a benchmark of minimal legitimacy for societies who values are different. (Gray 2009:40)
\end{abstract}

It is heretical to suggest that liberal wars have a religious motivation. When President George W. Bush referred to America's "War on Terror" as a "crusade" 5 days after $9 / 11$, his comment was swiftly retracted by the White House for fear of playing into the hands of Osama bin Laden who for years had characterized US foreign policy in the Middle East as a "crusade." 1 The fact that the British Prime Minister, Tony Blair, sought approval for the invasion of Iraq from Pope John Paul II-thereby echoing the medieval tradition of sanctified violence in which a crusade had to be declared by the pope-seemed trivial given that Blair arrogantly disregarded the pontiff's refusal to give his blessing to an unjust war. More fundamentally, liberal political orthodoxy decrees that liberal wars cannot be religiously motivated because they are fought to uphold secular ideals, principally human rights.

This article follows John Gray's lead in treating liberalism as a political religion (Gray 2009). It argues that insofar as liberalism represents a secularized version of Christianity, liberal wars represent distant ancestors of medieval crusades. This is different from crudely characterizing liberal wars as "crusades" outright, as Bush and bin Laden did. Liberal wars are patently not fought to uphold Christianity against the "threat" of Islam. But they are fought to uphold Western val-

\footnotetext{
${ }^{1}$ Bush claimed: "This is a new kind of - a new kind of evil. And we understand. And the American people are beginning to understand. This crusade, this war on terrorism is going to take a while" (Hodges and Nilep 2007:233). In 1998, bin Laden told his followers: "the call to wage war against America was made because America has spearheaded the crusade against the Islamic nation, sending tens of thousands of its troops to the land of the two Holy Mosques [...]" (Achcar 2002:58). The fact that America had recently intervened in Kuwait, Somalia, and the Balkans to save Muslim lives was evidently too inconvenient a truth to mention.

Hughes, David A. (2013) Liberal Warfare: A Crusade Twice Removed. International Studies Review,

doi: $10.1111 /$ misr. 12062

(C) 2013 International Studies Association
} 
ues believed to bear universal validity. In 1999, for instance, Tony Blair declared the Kosovo War to be "a just war, based not on any territorial ambitions but on values," arguing that "the spread of our values makes us safer." In 2005, 2 years into the Iraqi occupation, Blair's strategic adviser Sir Lawrence Freedman wrote of a "general Western confidence with regard to the universality of [Western] political values," claiming "Liberal wars are not pursued in the name of strategic imperatives but because values are being affronted" (Freedman 2005:97-98). The template is thus similar to that of medieval crusades: wars are waged, not out of strategic necessity, but to uphold "universal" Western values. At the same time, however, liberal wars are but pale imitations of the early crusades: if anything, they are akin to abortive late medieval attempts to rekindle something of the crusading spirit. Thus, liberal warfare represents "a crusade twice removed": it echoes a certain brand of late medieval warfare, which was in turn but a pallid derivative of the Crusades of the High Middle Ages.

The contemporary debate about liberal warfare began in earnest in the 1990 s when it centered on the notion of "humanitarian intervention." Since 2001, the central term of the debate has changed to the "responsibility to protect" (R2P). The US invasion of Iraq in 2003 widened the debate still further, with some commentators claiming that America's "War on Terror," too, could be classified as a "liberal war" (Freedman 2005). From start to finish, however, the entire debate about liberal warfare has been framed in the strikingly secular language of sovereignty, power, rights, law, and that wonderfully elusive term, legitimacy. Religion has not featured in any meaningful theoretical sense, only as the object of analysis within other theoretical frameworks, as when liberals speak of securing religious freedoms or when Realists cite religious identities as the basis of national identity and state sovereignty in certain parts of the world. As Jack Snyder observes, "mainstream international relations scholars find it difficult to integrate religious subject matter into their normal conceptual framework" (2011:2). This article attempts to do just that with respect to liberal warfare.

Liberals tend to follow the contention of Francis Deng and his coauthors, made amidst the "hyper-globalization" euphoria of the mid-1990s that "sovereignty carries with it certain responsibilities for which governments must be held accountable. And they are accountable not only to their national constituencies but ultimately to the international community" (Deng, Kimaro, Zartmann, Rothchild, and Lyons 1996:1). Following the NATO intervention in Kosovo and the Australian-led intervention in East Timor, UN Secretary General Kofi Annan voiced a similar sentiment: "State sovereignty, in its most basic sense, is being redefinednot least by the forces of globalisation and international cooperation. States are now widely understood to be instruments at the service of their peoples, and not vice versa" (Annan 1999:49). When states fail to protect their own people, authority to do so passes to the "international community through the UN" (ICISS 2001:13). According to this social contractarian logic, if states fail to live up to their responsibilities to protect the basic rights of their citizens (the idea of "human security"), then they forfeit their right to freedom from outside intervention. In that sense, the "society of states" represents something like liberal domestic society writ large: It is premised upon a bundle of rights and responsibilities that are, in principle at least, codifiable in the form of a legally binding (quasi-)constitution. The challenge therefore in liberal eyes is to bring legitimacy and legality into synch with one another by formulating a universal framework of standards that might one day serve as the basis for a new regime of international law.

Realists object that sovereignty cannot simply be "redefined" so as to make it contingent upon "responsible" behavior. As well as having a normative or de jure aspect (pertaining to its treatment in international law), it also, de facto, reflects 
coercive power as an empirical quality: It is inherently irresponsible insofar as it signifies potential for "action that cannot be susceptible to interference or accountability by another power" (Moses 2013:115-116). Although the champions of $\mathrm{R} 2 \mathrm{P}$ regard the $\mathrm{UN}$ as "the only credible international institution we have, or are ever likely to have, with the necessary combination of legitimacy and authority" to sanction humanitarian interventions (Evans 2008:180), in Realist eyes this in fact means the Security Council, a body of five sovereign states whose "irresponsibility" comes into view when they fail to reach agreement over an intervention. The "society of states" is in fact unlike domestic society, because there is no overarching authority to enforce the law impartially; only strong states have the power to do so. In which case, "the strong have no responsibilities, except to police the weak"; R2P "removes the "sovereign immunity' only of weaker states and not of the powerful" (Cunliffe 2006:54; Moses 2013:134). There can be no universal standard or legal regime, since powerful states are not obliged to obey; assuming as much only obscures the decisive and fundamental power relations upon which decisions about intervention can and should be made.

Critical voices argue that R2P offers a seductive and more sophisticated rationale for allowing powerful states to intervene in the affairs of the Global South. Just as Hitler used humanitarian rhetoric to justify the invasion of Poland, and just as the United States used humanitarian rhetoric to justify the invasion of Cuba in 1898, so today it is often suggested (especially by poorer or weaker states) that R2P "legitimizes" non-consensual intervention without the sanction even of the Security Council. Although R2P was first framed as "not making the world safe for big powers, or trampling over the sovereign rights of small ones" (ICISS 2001:11), the US invasion of Iraq shortly afterward did much to undermine that claim in the eyes of sceptics, making R2P appear as a "Trojan horse" for the legitimization of unilateral intervention (Bellamy 2008:617). From a critical perspective, too, international law can never truly be universalist, since its fundamental principles are Western, will never be used against Western states, and will always result in an imbalance of power in favor of the West (Jouannet 2007). Conversely, various attempts to agree new sets of "universal" human rights at the UN have foundered upon non-Western objections based upon very different cultural perspectives toward, say, women's or gay rights, or the more patriarchal approaches embodied in "Asian values" (Armstrong 2010:2134).

Constructivism has featured far less prominently in the debate about R2P, apart perhaps to lend support to liberal arguments by "treat[ing] the principle of sovereignty as a variable, arguing that its precise meaning and behavioral implications vary from one historical context to another" (Reus-Smit 1999:32), or to denaturalize the image of international anarchy and to promote international cooperation by depicting states as continually redefining their interests through routine participation in international discourse, in particular that of human rights. Here, in contrast, I want to deploy a constructivist approach in the opposite direction by asking how liberal interests have been constructed in the R2P debate. In particular, I mean to focus on the role of religion-specifically, the West's Christian inheritance. The argument, in a nutshell, will be that liberal wars are motivated less by the secular ideals of Enlightenment rationalism than by theological ideals traceable to medieval Christianity. Seen this way, "humanitarian intervention" and the "responsibility to protect" are problematic not just for the reasons given by Realists and critical thinkers, but also because they rest on assumptions about warfare that are five centuries or more out of date.

In what follows, the concept of political religion will first be explained, and the case will be made for treating liberalism as a political religion. Above all, this entails rejecting the myth that political and religious authority have always been separate in Western culture, as well as the myth that liberalism has, since the Enlightenment, managed to keep politics and religion at arms' length. Some of 
the features of liberalism qua political religion will then be observed, such as its teleological view of history, its belief in an ultimate harmony of truth and value, and its evangelizing impulse to universalize its own values. The link to liberal warfare will then be made, with the return of the just war tradition since 1948 being linked to the ascendancy of liberalism. Insofar as "universal" Western values are now invoked as a primary basis for going to war, it will be argued that the medieval "two swords" doctrine has also made something of a return in politico-religious form. However, while the ideal of waging war in the name of "universal" values persists, contemporary liberal wars have more in common with failed attempts to rekindle the crusading ideal in the late Middle Ages than they do with the Crusades themselves. Thus, an analogy will be drawn between liberal wars since the 1990s and attempts to revive the crusading impulse from the 1490 s on. In both eras, while contingent historical events are imbued with millenarian significance, actually mobilizing effective military operations on the basis of "universal" values proves fraught with difficulties. The conclusion points toward the dangers of waging war based on ideals derived from theology.

\section{Political Religion}

"Political religion" is not the same as, and is not to be confused with, "traditional religion." The latter, which is most readily identified with the major world religions (Buddhism, Christianity, Hinduism, Islam, Judaism, Sikhism, etc.), offers its adherents an ultimate horizon of meaning, or worldview, in which to believe. Usually (though not always), it requires a transcendental commitment from believers, principally a faith in a higher power(s) not of this world. It normally has a powerful metaphysical component that might be "revealed" through prayer or scripture. "Political religion," in contrast, refers to a political ideology that lays claim to the timeless truth and universal validity of a traditional religion without actually being one. It is a bastardized derivative of traditional religion that seeks to motivate absolute adherence to a secular cause among its followers by borrowing the language, concepts, and mythology of traditional religion and twisting them for its own ends.

"Political religion" is a contested concept: "there are problems of terminology, with political religion, secular religion, and religious politics all vying for the same semantic space, and sometimes jostling for position with other closely related terms such as millenarianism (apocalypticism, chiliasm) or civil (civic) religion" (Griffin 2005:11). For the purposes of this article, I will treat "political religion" as the dominant subset of "secular religion" (which also includes more minor forms of non-traditional religion such as the cult of celebrity and the "worship" of sports teams). "Political religion" is not the same as "religious politics," because it refers to a secularized version of "religion as a cultural system" (Geertz 1973/1993) rather than the politics of particular religious groups, organizations, and institutions. ${ }^{2}$ I differentiate "political religion" from "civil religion" below. Other terms such as millenarianism, apocalypticism, and chiliasm properly refer to specific traditions within Christianity (though their origins can be traced back further): political religion often appropriates elements of those traditions but is not identical with them.

Why bother with the term "political religion"? Certainly, when the term went out of fashion in the 1950s, there were those who thought it said little useful

\footnotetext{
${ }^{2}$ Clifford Geertz's famous definition of religion could apply just as easily to political religion as to traditional religion. According to Geertz, a religion is: “(i) a system of symbols which acts to (ii) establish powerful, pervasive and long-lasting moods and motivations in men by (iii) formulating conceptions of a general order of existence and (iv) clothing these conceptions with such an aura of factuality that (v) the moods and motivations seem uniquely realistic" (Geertz 1973/1993:90).
} 
about either politics or religion and merely caused confusion by oversimplifying both categories (see Cohen 2010:211). I would venture three reasons why "political religion" is a useful category, however. First and foremost, it challenges the liberal assumption that religion and politics can and should be kept safely apart, either by relegating religion to the private sphere or by "managing" religion when it appears in the public sphere (see below). As long as we remain wedded to that assumption, it is impossible to see that liberalism is not the "secular ideology" it pretends to be, but is, rather, a political religion derived from Christianity. Second, once we understand that liberalism is a political religion, we can cease viewing it as the polar opposite of "totalitarianism" and recognize that it has certain important features in common with communism, National Socialism, and fascism. This is not to overplay those continuities by any means, but it is to suggest a plausible explanation of why liberal states behave illiberally at times. Finally, thanks to the wave of recent scholarship on political religion, the term no longer suffers the conceptual imprecision that vitiated earlier writings on it, and therefore, there is no analytical reason to reject it. While this last reason speaks for itself, the other two are worth pursuing in greater detail, as I am now about to do.

\section{The Myth of Western Secularism}

Liberalism refuses to recognize itself as a political religion on the basis that it has traditionally been premised on the separation of politics and religion. Take Shklar's contention, for example: "liberalism refers to a political doctrine, not a philosophy of life such as has traditionally been provided by various forms of revealed religion and other comprehensive Weltanschauungen" (1989/1998:3). Or consider Daniel Deudney and John Ikenberry's claim: "Throughout the West, the dominant form of political identity is based on a set of abstract and juridical rights and responsibilities which coexist with private and semi-public ethnic and religious associations" (1999:193). Rodney Bruce Hall puts the matter even more bluntly: "religious identity in the liberal West is thoroughly relegated to the status of a cultural attribute within domestic society, a matter of personal preference no more significant in the civic order than is the individual's taste in music, food, clothing, or any consumer commodity" (1999:58).

Such claims could hardly be further from the truth. The idea that politics and religion can be divorced from one another is comparatively recent: it stems from the anticlericalism of the French Revolution and the attempt of thinkers such as Auguste Comte to envisage a society governed entirely by reason. From the beginning, however, the Comtean rationalist project was doomed to failure as "the revolution took on the trappings of church religion in the priestly power meted out to its demagogic leaders and in the slavish devotion to what it called the temple of reason" (Juergensmeyer 2008:15). Even before the French Revolution, the Westphalian state established in 1648 should more properly be regarded as "confessional" than "secular" (as IR's founding myth would have it), since rulers "used the capacity of religious traditions to engender social cohesion and mobilize allegiances in order to harden the boundaries between religious communities and make them coextensive with the boundaries of the state" (Mavelli and Petito 2012:934). In that respect, the "Westphalian presumption" (that the modern state separated politics and religion) has it precisely backwards: it is not that religious intolerance gave birth to the modern state, but that the founding myth of IR perpetuates the "myth of religious violence" (Cavanaugh 1995:398).

Contrary to claims that "God and Caesar, church and state, spiritual and temporal authority, have been a prevailing dualism in Western culture" and that "the Christian separation of religious and secular authority" persists "throughout the course of Christian civilization" (Huntington 1996:70; Scruton 2002:4-5), it 
is doubtful that religion and politics were ever truly separate in Western history. When Christianity was made the official religion of the Roman Empire in the fourth century $\mathrm{AD}$, for instance, religion and politics were purposely in synch: Christianity, conceived as a universal church, was intended to complement Roman law, conceived as a universal jurisdiction. Key thinkers in the late Patristic period such as St. Augustine, St. Gregory, and Pope Gelasius I may have sought to delineate spiritual and temporal spheres so as to cement the authority of the Church against the caesaropapism of the Byzantine Empire. Yet, the coexistence of the Pope and the Holy Roman Emperor following the coronation of Charlemagne in $800 \mathrm{AD}$ was always strained, and by the High Middle Ages any clear line between spiritual and temporal authority had evaporated. The papacy frequently intervened in politics on the basis of its "two swords" doctrine, claiming the authority to sanction crusades, wage wars of its own in central Italy, persecute heretics, excommunicate rulers, determine appointments to benefices, and arbitrate in political disputes. ${ }^{3}$

Although the Western Enlightenment separated Church and State, issuing in a legal or constitutional separation of religion and politics, it also spawned a range of political ideologies that drew heavily on Christian mythology in order to increase their social appeal and potency (Egerton 1983:498). For example, the Christian view of history as the unfolding of a providential design leading to a preordained telos (the Second Coming) is echoed in liberalism's faith in progress toward an age of "perpetual peace," the communist vision of revolutionary class struggle culminating in a socialist utopia, as well as the Nazi image of history as a social Darwinian dogfight leading to Aryan racial supremacy and a "thousand-year Reich." Similarly, the medieval millenarian conception of history as an earthly battle between good and evil has inspired all manner of radical groups to attempt to remake the world through violence, ranging from the Jacobins and the Bolsheviks to the Nazis and the neoconservatives. In this way, we see that "the rise of specific political ideologies is part of a much larger unfolding of ideas in world history, ideas that in most cases are colored in particular religious hues" (Juergensmeyer 2008:26). Like traditional religions, modern political ideologies have even been able to demand that citizens be willing to die for them: "The race, the nation, the ethnic group, and the class served as secular religions by offering an entire worldview that justified sacrifice" (Kaempf 2009:657).

In recent times, the "resurgence" of religion around the world, its motivation on political actors (most evident in religious fundamentalism), and the growing debate about post-secularism have finally prompted liberals to acknowledge the public face of religion. However, a new logic has emerged whereby liberals now try to promote the "good" or "moderate" forms of religion and to marginalize or expunge the "bad" (see Shakman Hurd 2012). Thus,

the enemy of Enlightenment is no longer "religion," now understood as one of
Europe's greatest moral assets, but fundamentalism: namely, those traditions of
religious practice that fail to accede to the universality of post-theistic Christianity
and therefore sit uncomfortably with the liberal sensibilities of modern
Europeans. (Hirschkind 2008:72)

In this way, secularism is being stealthily reconfigured in liberal discourse: no longer does it represent "a separation between religion and politics, but an

\footnotetext{
${ }^{3}$ Caesaropapism was where the emperor assumed ecclesiastical authority. The "two swords" doctrine depicted all temporal authority as deriving from, and subservient to, spiritual authority: it was coined by St. Bernard of Clairvaux in De Consideratione (ca. 1145-51) — not, as is almost universally thought, by Gelasius I — and was given its most forceful expression in the papal bull "Unam Sanctam" (1302). A good example of the papacy arbitrating in a political dispute was when it divided up the "rights" to the New World between Spain and Portugal in the "Inter Caetere" bulls of 1493 .
} 
ongoing, deepening entanglement in the question of religion and politics, for the purpose of identifying and securing fundamental liberal rights and freedoms" (Agrama 2010:502). Religion, that is, has been repackaged as something to be "managed" in accordance with liberal principles. There is still no sense in which liberals would acknowledge their own ideology as a political religion, even though (as we will see) the move to make religion align with liberal principles displays all the hallmarks of one.

\section{Political Religion, Totalitarianism, and Liberalism}

Historically, "political religion" first gained currency in the interwar years when it was used to refer to communism and National Socialism. Bertrand Russell, for example, wrote on his return from the Soviet Union in 1920 that "Bolshevism is not merely a political doctrine; it is also a political religion with elaborate doctrines and inspired scriptures" (cited in Gentile 2006:40). In 1925, John Maynard Keynes echoed Russell's sentiment by describing Leninism as "a religion and not merely a party," one that promised the realization of a new order and the regeneration of humanity (Gentile 2006:40). In 1943, Harold Laski observed in communists a "conviction that is religious in its profundity that they are bringing the inevitable future to birth [...] Their effort has for them all the elements of a crusade" (Gentile 2006:40). Beginning in the 1940s, Raymond Aron used the related term "secular religion" to describe and condemn communism. Eric Voegelin, in Political Religions (1938), extended the label "political religion" to National Socialism after being forced to flee Austria for the United States followed the Anschluss. Laski aside, the use of religion to describe communism and National Socialism carried a highly negative valence, intended as it was to highlight the ways in which those regimes' dogmatic faith in their own power to create the world anew dominated the conduct of every aspect of life against all rational evidence to the contrary. Insofar as no sacrifice was deemed too great to attain their utopian new orders-complete schemes of social salvation in which injustice, economic slavery, and war were to be abolished - the only sin was weakness. Any deviation from the "one true faith" was the equivalent of heresy in medieval Christianity, and it bore comparable consequences: condemnation, show trials, torture, and extermination.

"Political religion" went out of fashion in academic discourse during the second half of the twentieth century, in large part because of the influence of secularization theory from the late 1950 s on. Only in the last two decades or so has the concept witnessed something of a resurgence as scholars such as Emilio Gentile and Roger Griffin have sought to extend its franchise to Italian fascism as well as Soviet communism and National Socialism (Griffin 2005; Gentile 2006). The flagship journal of this trend is Totalitarian Movements and Political Religions, founded in 2000 by Michael Burleigh (rebranded as Politics, Religion, and Ideology in 2011). The original title of that journal reflects an important assumption in contemporary thinking about political religion that derives from the concept's origins in the 1920s: namely, that only totalitarian ideologies constitute "political religions." In part, that assumption probably owes to the fact that totalitarian ideologies display more overt religious characteristics than liberalism: "Nazism and Communism were political religions, each with its ersatz shrines and rituals" (Gray 2009:3). In Gentile's view, although religious themes are to be found in all modern political systems, the democratic analog of "political religion" is the more benign "civil religion"-viz. Robert Bellah's muchdisputed concept of "American civil religion" (Bellah 1967; Gentile 2006:141).

This distinction between (good) civil religion and (bad) political religion is untenable. For one thing, the two concepts relate to very different time periods and it is unclear that it makes sense to compare them. "Civil religion" goes back 
to Jean-Jacques Rousseau ${ }^{4}$ and the ideals of the French Enlightenment, where the aim was to manufacture a means of social control within a single state that would functionally supersede the authority of the Church. "Political religion," in contrast, is a twentieth-century term that seeks to imbue the authority of the modern state with universal significance. In that sense, "civil religion" seems to me to be a comparatively outdated concept unless one is referring to, say, attempts to manufacture secular nationalism in Arabic states. More problematic than the anachronism, however, is the fact that the two terms are not as dichotomous as Gentile would like to think. Even liberal democracies can (and often do) behave illiberally when motivated by politico-religious ideals, as we will see with respect to the United States.

Remember that while opponents of totalitarianism used the term "political religion" in order to denigrate communism and fascism in the interwar years, the reverse was also true: the Nazi sympathizer Carl Schmitt was scathing of liberal democracy in his book Political Theology (1922). "All significant concepts of the modern theory of the state are secularized theological concepts," Schmitt wrote (2005/1922:36). The idea of a single omnipotent God, he argued, had been recast as that of the sole sovereign or omnipotent lawgiver, only Enlightenment rationalism had imparted a distinctly deist conception whereby the sovereign never intervenes directly in the law but instead presides over it, rendering "the exception in jurisprudence [...] analogous to the miracle in theology" (Schmitt 2005/1922:36). Ever since Descartes' claim that "It is God who established these laws in nature just as a king establishes laws in his kingdom," "the lawfulness of nature and normative lawfulness" had become conflated in Schmitt's view: Both were deemed to be universally valid when in fact the legal order could be suspended by an act of sovereign decision Schmitt (2005/ 1922:47, 41). Therefore, pro-democratic legal theorists such as Hans Kelsen were guilty, in Schmitt's judgment, of misapprehending the nature of the political: Their legal universalism ignored "the decisionistic and personalistic element in the concept of sovereignty," because it derived from a rationalist interpretation of theological ideals (Schmitt 2005/1922:48).

\section{Liberalism Qua Political Religion}

We need not share Schmitt's preference for dictatorship in order to recognize the validity of his diagnosis of liberalism in terms of political theology. For despite feigning to maintain a categorical distinction between politics and religion, liberalism is shot through with ideas and mythology deriving from medieval Christianity. For example, liberalism inherits Christianity's faith that history has direction and is unfolding in accordance with a particular design. For Christians, that design goes by the name of Providence: it means that human history is, in accordance with divine will, moving toward an endpoint when God's plan for humanity will finally be realized. Depending on the particular mythology being followed, the Christian End of History may be marked by the Second Coming of Christ, who will reign for 1,000 years after vanquishing the Antichrist at Armageddon (Revelation 16:16), the appearance of "the new Jerusalem descending from heaven" (Revelation 21:2), and/or the Rapture in which those "who are alive and remain" will be "caught up in the clouds" to meet "the Lord in the air" (Thessalonians 4:17). For liberals, the "coherent and directional History of mankind" similarly unfolds in accordance with timeless and universal principles-liberal principles, which in the eyes of believers are without equal in the realm of ideas: "there is not a higher set of alternative principles that will in time replace them" (Fukuyama 1992:xii; Fukuyama 1995:30). The liberal

\footnotetext{
${ }^{4}$ Book 4, Chapter 8 of The Social Contract.
} 
conception of progress derives from Christian providentialism and sees history as moving in accordance with reason rather than God's will. For liberals, history is moving "toward perpetual peace": an age when major conflict will be no more (Kant 1795). This is neither a smooth nor a linear process, for there will always be historical backsliding based on human imperfection (as when "waves" of democratization crest and recede). Nevertheless, much as the Apocalypse marks the final triumph of Christianity, so "the end of history" denotes the cessation of ideological evolution and the final triumph of liberalism (Fukuyama 1989). ${ }^{5}$

Still, there is a marked contrast between the Christian "end of history," which claims to give ultimate meaning and purpose to human existence, and the banal, secularized "end of history" promised by liberalism. Almost as an afterthought, Fukuyama concluded his famous article:

\begin{abstract}
The end of history will be a very sad time. The struggle for recognition, the willingness to risk one's life for a purely abstract goal, the worldwide ideological struggle that called forth daring, courage, imagination, and idealism, will be replaced by economic calculation, the endless solving of technical problems, environmental concerns, and the satisfaction of sophisticated consumer demands. In the post-historical period there will be neither art nor philosophy, just the perpetual caretaking of the museum of human history. I can feel in myself, and see in others around me, a powerful nostalgia for the time when history existed [...] Perhaps this very prospect of centuries of boredom at the end of history will serve to get history started once again. (1989:18)
\end{abstract}

Fukuyama's tone here is wistful, not triumphant, for with liberalism's "triumph" all that cometh is Nietzsche's "Last Man": the apathetic, risk-averse bourgeois who, lacking any great cause or incentive to greatness, contents himself merely with his own comfort and security (Fukuyama 1992). This is not so very far away from Keynes' observation of communism: "like other new religions, it seems to take the colour and gaiety and freedom out of everyday life and to offer a drab substitute in the square wooden faces of its devotees" (cited in Gentile 2006:40). We therefore find good reason to be suspicious of political religion, since even when it ostensibly achieves its goals they turn out not to be all they were cracked up to be, making us wonder on what authority political religion makes such high demands of its adherents.

In the Augustinian tradition of Christianity, the New Jerusalem (the City of God) has nothing to do with earthly politics (the City of Man): it represents a spiritual ideal to be aspired to through piety. In the millenarian tradition of the High Middle Ages, in contrast, the New Jerusalem is something to be realized here on earth. The battle between good and evil is seen not as merely spiritual but, rather, directly political:

Sacred violence always stemmed from the conviction that Christ's wishes for mankind were associated with a political system or course of political events in this world. For the crusaders his intentions were embodied in a political conception, the Christian Republic, which was thought to be a single, universal, transcendental state ruled by him, whose agents on earth were popes, bishops, emperors and kings. (Riley-Smith 1987:xxviii)

Liberalism both inherits this ambition to build a universal regime based on its own values and is torn by a similar dilemma about how best to do so. On the one hand, there is the Kantian/meliorist/communitarian variety of liberalism that holds that liberalism must be allowed to evolve organically-through virtu-

\footnotetext{
${ }^{5}$ It should perhaps be noted that the ideas of an underlying design to the universe and an age of perpetual peace both derive from ancient political thought: from natural law theory in the first case and Virgil's imagery (in his Fourth Eclogue) of a new Golden Age in the second.
} 
ous conduct, so to speak - and that history cannot be accelerated by waging war to impose liberal values on non-believers. On the other hand, we find the Painean/messianic/cosmopolitan variety of liberalism that treats military intervention as justifiable wherever violations of liberal values are to be found in the conviction that those values will flourish once obstacles to their realization are removed (Walker 2008; Doyle 2011).

In the contemporary world, we see this dilemma played out in the different foreign policy orientations of the Bush and Obama administrations in the United States. Whereas George W. Bush presided over a regime intent on deploying America's colossal military might in order to spread liberal values through "regime change" in the Middle East (in the belief that those "universal" values would automatically take root as soon as tyrants were toppled), President Barack Obama has leaned in the opposite direction, being keen to get out of Iraq and Afghanistan, hard to convince to go into Libya and Syria, and harder still to convince to bomb Iran. He has, of course, been rewarded with a Nobel Peace Prize for his efforts, but this should not blind us to the fact that he is pursuing the same goal as Bush - a universal liberal regime, with the United States at the helm-just within a different tradition of liberalism. Thus, one should be careful not to overstate the foreign policy differences between the two administrations. As Michael Desch has observed, the Obama administration has in fact continued many Bush-era initiatives, some of which, particularly those relating to the "War on Terror," display a profoundly "illiberal" character in the eyes of their critics. ${ }^{6}$

There is, indeed, a flip side to claiming to champion "universal" values: it makes one remarkably intolerant toward anyone who disagrees with those values or with one's own interpretation of those values. Here, we owe a debt of gratitude to Gray for his repeated assaults down the years on liberalism's claims to reasoned tolerance, metaphysical neutrality, and universal validity (see Gray 2009). Far from embodying these qualities, American liberalism all too often follows in the tradition of Plato and Aquinas by presupposing an ultimate harmony of truth and value, whereby conflicts of value are read as symptoms of error that in principle can always be resolved rather than fundamentally contradicting liberal ideology. Arguably, the best example of this is Rawl's (1993) "political liberalism" that imagines itself as allowing people of all faiths to live peacefully side by side based on a set of abstract rights and responsibilities. For all its claims to toleration, however, Rawls's political liberalism finally insists on a single right way, its own:

[Even] in the case of predominantly illiberal-and specifically theocratic-socie-
ties, Rawls suggests that [...] traditional texts have been misunderstood or mis-
represented by orthodoxy: liberalism will then be so far from metaphysically
neutral that it will actually rely on some sort of liberal theology. (Fortier
2010:1012)

Rawls' call for a reinterpretation of Islam so as to bring it into line with liberal principles (much as Enlightenment philosophers liberalized Christianity) recalls the famous letter written (but apparently never sent) by Pope Pius II to Mehmed II in 1461 in which the pontiff sought to persuade the Ottoman Sultan of the

\footnotetext{
${ }^{6}$ Desch (2010) points to the efforts of both regimes to counter nuclear proliferation to anti-American regimes such as Iran and North Korea as well as their shared (and his view overblown) rhetoric of "existential threat" from Iran's nuclear program. He also notes that both regimes have framed the anti-terrorist struggle as a "war" rather than a criminal matter; that the Obama regime has escalated that "war" through the use of unmanned aerial vehicles (or drones); that the Guantanamo Bay "detention facility" remains open and that Bush-era military commissions have been altered but not eliminated; that detention without trial and extraordinary rendition have been reduced but not ruled out; that the Bush regime's program of expansive domestic surveillance has not been curtailed; and that America's seemingly unconditional support for the State of Israel persists.
} 
superior reasonableness of Christianity to Islam (Stinger 1998:119). As Gray points out, however, "It is a mark of an illiberal regime that conflicts of value are viewed as signs of error [...] Liberalism of this kind is a species of fundamentalism, not a remedy for it" (Gray 2009:39).

Jürgen Habermas has sought to update Rawls' "political liberalism" for the twenty-first century by allowing that religious language does, after all, have a place in the public square. According to Habermas, a compromise is needed:

\footnotetext{
The religious side must accept the authority of "natural" reason as the fallible result of the institutionalized sciences and the basic principles of universalistic egalitarianism in law and morality. Conversely, secular reason may not set itself up as the judge concerning the "truths" of faith - even though in the end it can accept as reasonable only what it can translate into its own, in principle universally accessible discourse. (Habermas 2010:16)
}

On this view, religion offers a means of addressing important ethical and political questions in increasingly pluralist societies otherwise wedded to markets and bureaucracies - provided, however, its insights can be "translated" into "universally accessible" rational discourse. However, not only is Western metaphysics' false dichotomy between immanent/natural and transcendent/religious spheres simply recast here in linguistic discourse (Dallmayr 2012:967), but "reasonableness" once again prevails: religion is permitted to show its face in public provided it adheres to the rational and allegedly universal dictates of liberalism.

It is telling that Habermas should have been influenced by the Regensburg address of Pope Benedict XVI in 2006, when the German pontiff spoke of the Christian belief that reason and revelation are in harmony with one another (as evidenced by Augustine and Aquinas's attempts to synthesize Greek metaphysics and biblical faith). Although Habermas was also critical of the pope's position, his own standpoint in many ways represents a secularized version of it. Habermas presupposes the same ultimate unity of faith and reason, only his own faith here is in liberalism rather than Christianity. Habermas has thus become an acolyte for the political religion of our time.

\section{The Return of the Just War Tradition and the "Two Swords" Doctrine}

If we treat liberalism as a political religion, then liberal warfare begins to assume a very different complexion from the kind we are familiar with in contemporary debates about the justification for military intervention in the affairs of other states. Far from boiling down to a utilitarian calculus of how to maximize the greater good (liberalism), or an empirico-legal question of when sovereignty may or may not be violated based on considerations of power (Realism), or a masquerade for Western imperialism (critical theory), the rationale behind liberal wars starts to look more like an attempt to rekindle something of the medieval crusading impulse in secularized form.

A preliminary indication of this is the revival of the medieval just war tradition since 1948. That tradition faded in significance following the Peace of Westphalia, in whose various treaties " $[\mathrm{t}]$ he concept of the just war was nowhere mentioned. It had become irrelevant" (Bobbitt 2002:507). In place of the respublica Christiana, as the modern state system crystallized, stood "[t]he idea of a juridical order without a higher political or ecclesiastical authority" (Bobbitt 2002:508). Ever since 1648, the conventional wisdom goes, "[t] he Westphalia legacy of international order, based on the twin principles of state sovereignty and non-intervention, has been the basis of international law, the realist theory of international relations, and the practice of diplomacy" (Hehir 1992:243). While the Weberian image of the modern state as a discrete, territorially bounded unit 
proves to be a Eurocentric myth (see Barkawi 2010), the emergence of the modern state did put paid to the universal legal structures of Latin Christendom upon which the medieval just war tradition depended.

Since the end of World War II, the world has witnessed an increasing return of the just war tradition-not to sanctify Christian holy war, to be sure, but, rather, to legitimate violence deployed on behalf of the West's new political religion: liberalism. The most important legal codifications of that tradition-in particular its concern with the jus ad bellum and jus in bello-can be found in the United Nations Universal Declaration on Human Rights (1948) and its subsequent covenants (1966, ratified 1976), as well as the Geneva Conventions (1949) and their Additional Protocols $(1977,2005)$. These documents do not represent a sudden "break" in the history of international law, for not only were they foreshadowed by the Hague Conventions $(1899,1907)$, but the "Westphalian" principles of state sovereignty and nonintervention remained dominant throughout the Cold War era and arguably beyond. From their inception, however, those documents were

\begin{abstract}
regarded as a significant crack in the shell of state sovereignty. In contrast to the pre-UN regime, when human rights violations were regarded as matters of "domestic jurisdiction," the UN texts affirm an obligation on the part of states to defend human rights in states found guilty of persistent and gross violations of rights. The evolution of this process has been slow and halting [...] Nevertheless, the assertion of responsibility for human rights sets limits to the sovereign claims of states. (Hehir 1992:244)
\end{abstract}

Insofar as a global regime based on universal moral imperatives now asserts a higher political jurisdiction than state sovereignty, meeting resistance in the process, the world since 1948 has come to resemble Western Christendom pre-1648.

Along with the just war tradition, the medieval "two swords" doctrine has also returned in politico-religious form. ${ }^{7}$ In the Middle Ages, Rome claimed "authority for use of the sword, both to protect true religion and to punish dissent and heresy, and also to oppose temporal rulers judged guilty of misgovernment, especially if that were manifest in opposition to the true religion of the Catholic Church" (Johnson 2003:13). Wielding the spiritual sword, the pope could excommunicate his enemies or impose other forms of ecclesiastical discipline on them; and with the temporal sword he could authorize the use of military force against them-this despite the patent flimsiness of the Biblical analogy cited in support of the "two swords." A fitting symbol of this is the first recorded papal gift of a sword to a secular ruler in 1357, which later became an annual custom (the recipient of the sword being seen as blessed with divine favor in warfare). Today, we see a similar logic at work: rulers deemed guilty of violating the one true faith of liberalism can have pressure of all kinds brought to bear against them. Liberals never tire of telling us that R2P is not just about war: "We need

\footnotetext{
${ }^{7}$ According to St. Bernard of Clairvaux in De Consideratione (ca. 1145-51), a book of advice to Pope Eugenius III, the pontiff possessed two swords to suppress evil, one spiritual, the other temporal or material. The first was only his to use, but the second he could delegate to a secular ruler to use at his bidding: "The [material] sword also is yours and is to be drawn from its sheath at your command, though not by your own hand" (cited in Chambers 2006:13). This provided the theological justification by which the pope was able to authorize crusades, with religious orders such as the Knights Hospitaller and the Knights Templar wielding the material sword on his behalf. It served as a means of reconciling the peaceful example of Christ and the pacifism of the clergy with the millenarian impulse to reconquer the Holy Land. It explicitly did not condone war waged in the papacy's temporal interests, since St. Bernard reproached Eugenius in 1149 for deploying Sicilian troops and the papal militia to overcome the seditious Roman commune.

${ }^{8}$ The Biblical foundation fancifully invoked by St. Bernard comes in Christ's seeming approval of the Apostles possessing two swords at the Last Supper- "And they said, Lord, here are two swords. And he said unto them, It is enough" (Luke 22:38) — and the fact that St. Peter himself clearly wields the material sword (John 18:10-11).
} 
constantly to remind people that this is not humanitarian intervention and that this is not all about the use of force" (Luck 2009:36). But all they are really doing here is wielding liberalism's other sword: the one that makes a pariah out of the enemy through diplomatic pressure, economic and legal sanctions, and cultural condemnation. The same zeal to instill conformity (to liberalism rather than Christianity) and to punish non-conformity has not disappeared since the Middle Ages.

The Catholic apologist James T. Johnson, writing at the time of the Iraq War, finds himself caught in a double bind when trying to justify "regime change" in terms of just war theory's requirement for legitimate state authority. ${ }^{9}$ On the one hand, he recognizes that the "two swords" doctrine served to inflame the wars of religion, with Protestant rulers following Martin Luther in claiming a strict separation of religious and secular authority in opposition to papal orthodoxy. Linking Luther's position back to St. Thomas's (and St. Augustine's) requirement for legitimate (that is, sovereign) authority for just war, Johnson claims that "the 'two swords' position [...] was never in fact deeply rooted in Christian doctrine or law, and after [1648] it disappeared" Johnson (2003:15). By extension, the only credible position is the "one sword" doctrine that segregates spiritual and temporal spheres and does not allow religious considerations to motivate warfare. Again, one thinks here of the myth of Western secularism: "throughout the course of Christian civilization we find a recognition that conflicts must be resolved and social order maintained by political rather than religious jurisdiction" (Scruton 2002:5). Johnson fails to see, however, that his own argument imports a secularized version of the "two swords" doctrine by appearing to advocate regime change in cases where "legitimate" authority is violated. In fact, the requirement for legitimate state authority in the just war tradition has always been double-edged: Although it means that only sovereigns can legitimately declare war (as opposed to private individuals, such as in the German Peasant's War in the 1520 s, or the terrorists of today's world), it also means that rulers can be justly deposed if they violate "universal" codes of "legitimate" conduct. The "two swords" doctrine, so central to papal ideology between the fourteenth and seventeenth centuries, was anything but the aberration Johnson pretends. On the contrary, it left its mark so indelibly on Western political thought that it has resurfaced today, in politico-religious form, as a way of legitimating coercive regime change.

\section{The End of History in Historical Context}

While the post-1948 world bears some resemblance to pre-1648 Latin Christendom, it would perhaps be more accurate to say "pre-1517" than "pre-1648," since the dream of a universal liberal regime still seems eminently achievable in the eyes of believers, much as the utopia of a universal Christian civilization filled the minds of the faithful before Latin Christendom was torn apart by sectarian violence following the Protestant Reformation. In the remainder of this article, I will argue that the urge to spread and uphold liberal values through warfare since the 1990s has much in common with still-born attempts to revive the crusading initiative following the conquest of Granada and the discovery of the New World in the early 1490s. This analogy should be taken in the spirit in which it is offered: not as implying any "thick" or necessary correspondence between the two eras, but, rather, as a heuristic device intended to illustrate the politico-reli-

\footnotetext{
9"[R]emoval of a tyrant-'regime change' in contemporary parlance-was first the responsibility of proper sovereigns, who (by contrast with private persons of whatever social rank) had the right of using the sword for the public good" (Johnson 2003:18, n.1).
} 
gious contours of contemporary liberal warfare by noting their similarities with an earlier era of religious warfare in the West.

With the reconquest of Granada on January 2, 1492, which reunified Spain after seven centuries of division between Christians and Muslims, and Christopher Columbus's discovery of the New World in 1493, it seemed to many Christians as though centuries of Muslim incursions were, gloriously and unexpectedly, about to be rolled back. According to Sigismondo de' Conti, for instance, "Christian ears had heard nothing but sad and terrifying news of Muslim exploits for some 40 years. Now came a great Christian victory. Did not the capture of Granada in the West offset the loss of Constantinople in the East?" (Setton 1978:424). Certainly, when the giant silver cross gifted by Sixtus IV to the Spanish Monarchs was raised above the Alhambra, there was a mood of immense spiritual exaltation throughout Latin Christendom. In the eyes of papal preachers, their own time marked the plentiudo temporum - the "fullness of time" or the climax of human history - a Biblical notion traceable to Ephesians 1:10: "And he made known to us the mystery of his will according to his good pleasure, which he purposed in Christ, to be put into effect when the times will have reached their fulfillment-to bring all things in heaven and on earth together under one head, even Christ." In the 1490s, indeed, the idea of one flock, one shepherd "had the messianic sense of creating, under papal headship, the plenitudo gentium, a brotherhood of the whole human race. The spread of the gospel to newly discovered parts of the globe seemed an auspicious sign that this fraternal union was indeed emerging" (Stinger 1998:301). Roman humanists thus anticipated the union of all peoples in a new Golden Age of peace and concord.

The events of 1989/90 prompted similarly messianic visions on the part of American ideologues. On the eve of German reunification, as the Berlin Wall came down and the Soviet Union unexpectedly disintegrated, Fukuyama proclaimed "the end of history" and suggested that liberal democracy could emerge as "the final form of human government" (Fukuyama 1989:3, 5). Fukuyama's argument follows a pattern of promise, fulfillment, and transcendence that will be familiar to students of Christian theology. Christ's coming was prophesied in the Old Testament and realized in the New Testament, pointing forward to the end of human history with his Second Coming. Along similar lines, Fukuyama assigns liberal values a sacred character by assuming them to be timelessly true; he sees the historical validation or fulfillment of those values in the triumph of liberalism over communism and fascism; and he interprets that validation as pointing forward to the end of history in the sense of the absence of major conflict. Fukuyama was hardly alone in his millenarian tone. The erstwhile "New World," 10 it was said, had become the center point of a "new world order" $" 11$ in which "peacekeeping" would replace conventional warfare. The United States would preside over this universal regime - a role that "did not supplant America's founding purpose but pointed toward its fulfillment-and the fulfillment of history itself. To President Bill Clinton, the moment signified that 'the fullness of time' was at hand" (Bacevich 2002:52).

It is all too easy to read the discovery of the New World in terms of the pillaging and enslavement that followed. Yet, "At least in the early days of the conquest of America the impact of the crusading ideal upon this new kind of venture is very clear" (Keen 2005:251-252). The Conquista itself was not a cru-

\footnotetext{
${ }^{10} \mathrm{~A}$ phrase first used by Peter Martyr d'Anghiera in a letter dated November 1, 1493, in which Columbus is referred to as the discoverer of the "New World" (novi orbis).

${ }^{11}$ A phrase first popularized by President George H. W. Bush from the summer of 1990 to the end of March 1991 following Iraq's invasion of Kuwait. The rhetorical force of the phrase was to imply that Iraq was defying not just the United States and its traditional allies, but the "international community" as a whole. In other words, it implied universal validity of liberal principles.
} 
sade, but it did draw on the crusading tradition: Pope Alexander VI "saw exploration as a glorious means to evangelize pagans [...] He saw [its fruits] not as a means to conquest, or as enterprises for the rape of distant lands, but as ventures for the propagation of the faith" (Johnson 1981:216). Indeed, it is telling that "Alexander VI's famous bulls of 1493, that conceded the islands found by Columbus to the Spanish crown, emphasized also that along with rights of possession went the responsibility to propagate the Gospel to the inhabitants of new-found lands" (Stinger 1998:120). So it was that Benedictine friars and 12 other priests accompanied Columbus during his second voyage to the New World, and "it was for God as well as gold that Westerners went out to conquer the world in the sixteenth century" (Huntington 1996:70). Indeed, the prodigious Christianizing enterprise by Spanish and Portuguese missionaries and the ruthless feats of the conquistadors went hand in hand.

A similar evangelizing impulse was again evident in Western culture five centuries later: "The end of the Cold War was followed by a period of triumphal delusion, with the victorious powers acting as missionaries for their own version of political religion - a belief in democracy as a universal panacea" (Gray 2009:7). As President Clinton pursued a project of "democratic enlargement," many Americans recognized a moral "duty to democratize." Revealingly, Bobbitt (2002:265) refers to this branch of US foreign policy as "New Evangelism" - a clear allusion to its Christianizing heritage. In economic terms, meanwhile, "The macroeconomic policies known as the Washington consensus became gospel in international financial institutions" (Drezner 2009:320) and "the IMF and the World Bank became the new missionary institutions, through which these ideas were pushed on the reluctant poor countries that often badly needed their loans and grants" (Stiglitz 2002:12).

It was in this climate of secular proselytization that the idea of liberal warfare began to gain currency. The rate of humanitarian interventions increased enormously during the 1990s: These were wars whose primary motivation was not the self-interest of states but the mission of upholding liberal values. The discursive shift from a "right to intervene" to a "responsibility to protect" following the Kosovo Commission's finding that NATO's invasion of Kosovo had been "illegal but legitimate" (ICISS 2001:7) only underscored the fundamentally moral or spiritual, rather than legal, basis of liberal warfare. It is important to note that this new type of warfare transcends party-political divisions. In 2002, for instance, President George W. Bush declared it was "America's duty" to build a "just peace" conducive to "human liberty." The end of the twentieth century had, he claimed, witnessed the triumph of "a single surviving model of human progress" that America stood ready to promote. The continuities with Fukuyama's "End of History" thesis and Clinton's "duty to democratize" should be obvious enough.

It is telling that the United Nations High-Level Panel on Threats, Challenges, and Change referred to R2P as an "emerging norm" in its 2004 report, "A More Secure World: Our Shared Responsibility." Liberals tend to take the idea of an "emerging norm" for granted, viz. Michael Doyle's opening gambit: "One of the truly striking evolutions in international norms of our time is the development of the Responsibility to Protect" (Doyle 2011:72). Even those who recognize that it is still too early to speak of R2P as a legal norm write of "a growing transformation of international law from a state- and governing-elite-based system of rules into a normative framework designed to protect certain human and community interests" (Stahn 2007:100). Such language of emergence and transformation reflects liberals' metaphysical faith that history is moving in the direction of a universal liberal regime. Decolonization, the end of the Cold War, and globalization have all worked, in liberal eyes, to foster global interdependence while lessening the constraints placed upon the UN by great power rivalry. The tendency is thus said to be toward a "unified standard for national, regional, and global 
action" enforceable through international institutions (Luck 2009:38). Those who would beg to differ are met with an intolerant insistence that the liberal way is the one right way: "Realists will need to acknowledge that RtoP is becoming part of what constitutes the conventional standards of stabilizing behavior [...] Socialists [...] will also need to acknowledge that there is a new floor and standard for acceptable national policy" (Doyle 2011:83). Once we treat liberalism as a political religion, however, then such guiding assumptions appear more as a product of theology than reason-and as we will see below, there are in fact good reasons to contest those assumptions.

\section{The Coming of the Millennium}

The vision of ushering in the end of history through warfare derives from the Christian millenarian tradition. But so too does the will to "pacify" the region now known as the Middle East. This goes back to the early Crusades and the felt need to reverse the rapid incursions into Christendom made by Islam in previous centuries. In the 1490 s that desire was as strong as ever. Columbus, for instance, having failed to receive royal backing for his voyages in 1486, urged the Spanish Monarchs in 1492 to "spend all the profits of this my enterprise on the conquest of Jerusalem" (Columbus 1988:291). He thereby drew on the Franciscan prophetic tradition that envisioned the spiritual conquest of Islam, the liberation of Jerusalem, and the conversion of the Jews as preludes to the second coming of Christ. The reconquest of Granada and the expulsion of the Jews from Spain in 1492 indeed seemed to contemporaries to herald the coming of the millennium, and Ferdinand was proclaimed a "new Charlemagne" whose destiny was to liberate North Africa and Jerusalem from Muslim rule. There followed "a notable series of conquests, authorized by the popes and justified by the ancient idea of reaching the Holy Land by way of the African coast" (RileySmith 2005:279). In 1498, Columbus estimated in his Book of Prophecy that the Second Coming was only a few decades away and even referred to himself as a messiah.

When news reached Rome in 1507 of three startling Portuguese successes in the Far East, ${ }^{12}$ they too were interpreted in explicitly millenarian terms by the papal preacher Giles of Viterbo:

\footnotetext{
Giles emphasized that the expansion of the Christian imperium beyond anything previously known constituted a clear sign of the impending union of all mankind in peace and concord. At last the time was propitious for a crusade. Once Antichrist (the Ottoman infidel) was defeated and the holy places in Jerusalem and Palestine recovered for Christendom, then the Johannine promise of one shepherd and one sheepfold would be fulfilled. (Stinger 1998:121)
}

Indeed, the papacy's crusading ambitions had been inflamed ever since 1492. When the Spanish cardinal Rodrigo Borgia was made pope a few months after the fall of Granada, he chose the name Alexander VI so as to invoke the military feats of Alexander the Great, a fact that was not lost on contemporaries. The Cardinal Grand Master Pierre d'Aubusson, for instance, reminded the new pontiff: "Alexander the Great once conquered the East and reduced it to a single state" (Setton 1978:435). Pietro Cara, ambassador of Savoy, urged the pope to show "great severity towards the Turks and behave as a new Alexander the Great towards those kings of the East and their people that know not Christ" (Poeschel 1988:73).

\footnotetext{
${ }^{12}$ Namely, the discovery of Madagascar, the placing of Ceylon under tribute, and the naval victory over the fleet of the Zamorin of Calicut.
} 
In our own time, millenarian fervor has been vividly embodied in the "Bush Doctrine": the deluded idea that US national security goes hand in hand with democratization of the Middle East. Granted, "peace in the Middle East" no longer has to do with reconquering the Holy Land for Christianity, but it does still have everything to do with "Westernizing" the region (in the sense of exporting liberal values and institutions to it). As Gray satirically puts it, "Liberalism is nothing if it is not a crusade, and the Middle East clearly needs conversion" (Gray 2009:291). Bush repeatedly reduced the complexities of international politics to an earthly battle of "good" vs "evil," and his administration clearly saw the Middle East as the battleground. On November 6, 2003 Bush decreed:

\begin{abstract}
The establishment of a free Iraq at the heart of the Middle East will be a watershed event in the global democratic revolution [...] America has put our power at the service of principle. We believe that liberty is the design of nature; we believe that liberty is the direction of history [...] And we believe that freedom - the freedom we prize - is not for us alone, it is the right and the capacity of all mankind.
\end{abstract}

War here is justified, not through any strategic calculus, but in terms derived from theology: history represents the unfolding of a providential design in accordance with natural law and can therefore be accelerated by those who understand that design. Augustine's contention that only God can know the design of history therefore proves irrelevant, as do the lessons of history themselves: when the Bolsheviks tried accelerating history in the October Revolution, for instance, the consequences for the twentieth century proved catastrophic.

\title{
The End of Crusade and the Future of Liberal Wars
}

Despite the crusading fervor in Latin Christendom on the eve of the Reformation, actually mounting a successful crusade proved all but impossible. For one thing, the millenarian ideal of remaking the world through warfare bore no relationship whatsoever to historical reality. On the one hand, the fall of Constantinople in 1453 - the extinction of "one of the two lights of Christendom," as the future Pope Pius II (1458-64) put it in a letter to his predecessor, Nicholas V (1447-55) - had "made urgent some form of military response to this dramatic show of strength. Despite longstanding western awareness of the Byzantine capital's jeopardy, its capture was profoundly shocking" (Stinger 1998:112). In subsequent decades, the papacy therefore found itself "trying to revive something of the crusading initiatives of the great medieval popes from Urban II to Innocent III" (Chambers 2006:48). Yet, the Ottoman Empire "was in command of military might overwhelmingly superior to any single expedition of Christian knights" (Stinger 1998:111). The Crusade of Nicopolis (1396) is sometimes considered the last large-scale crusade: the Franco-Burgundian nobility relied on the frontal charge of heavily armored knights and was duly decimated. For others, "the last crusade based on the medieval model" was the Crusade of Varna (1444), which ended in devastating defeat for the Hungarian and Polish armies on the shores of the Black Sea (Stinger 1998:112).

The crusading ideal was thus hopelessly anachronistic by the late fifteenth century. It is true that "The crusades did not fade from the horizon of politics because of a decline of holy zeal [...] If anything they had rather too much of it, as the history of the religious wars of the Reformation period testifies" (Keen 2005:251). Rather, as time went on, the crusading ideal was increasingly subordinated to state-building imperatives. This was as true of the papacy as it was of great powers such as Spain-where the war against Granada represented "the crusade harnessed by the monarchy for the business of state-building" (France 
2005:290) - and France, as when Charles VIII used crusade as a pretext for invading Italy in 1494. In the space of a few decades, an important shift had taken place: rather than spiritual ideals providing the justification for warfare, secular developments had come to provide the pretext for invoking crusade.

By the 1490 s, when the crusading ideal was in many ways more alive than it had been in many decades, if not centuries, it had become fatally vitiated:

\begin{abstract}
Over time, $[\ldots]$ as so many proclamations of crusade, so many diplomatic missions, so many congresses, so many abortive campaigns failed to eradicate, or even come to grips, with the Ottoman menace, the currency of crusade became devalued. When crusading tenths became part of the normal income of the Spanish crown (and spent in Italian wars), when Alexander VI made overtures to Bayezid for assistance against the Italian invasion of Charles VIII of France in 1494, when the same pontiff sanctioned the partition by France and Spain of the Kingdom of Naples in 1501 as being in the interests of the crusade and diverted crusading funds to finance Cesare's campaigns in the Romagna, then the whole notion of crusade became just another negotiable item in the tangled skein of international politics. (Stinger 1998:118)
\end{abstract}

Note that the papacy itself was, by the late fifteenth century, the most spectacular culprit in debasing the idea of crusade as state-building imperatives skewed papal interests ever further in a secular direction.

The demise of medieval crusades was cemented by the French invasion of Italy in 1494, an event that began the Italian Wars that would last until the Peace of Cateau-Cambrésis (1559). "[I]n the sixteenth century, Christians became busier than ever fighting other Christians" (Keen 2005:252), and the immediate imperative of survival was far more pressing than high-minded ideas about crusade:

\footnotetext{
The nature of inter-state politics and the chaos into which Italy fell from 1494 onwards made it impossible to persuade the princes to sink their differences for long enough. They could always be convinced that a dispute with a neighbour or a justifiable claim was more important than the Turkish threat to Europe. (RileySmith 2005:281)
}

In fact, one could reasonably mark the death of the crusading ideal somewhere during this period (Riley-Smith chooses 1517) on the basis that the universal respublica Christiana on whose account crusades were fought was increasingly undermined by secularization until it finally fractured with the Protestant Reformation.

Like late medieval crusades, liberal wars are far too ambitious in their universalizing aspirations. Much as the former were undone by their reliance on a feudal paradigm of warfare at a time when modern techniques of war were obviously superior, so the latter rely on a modern paradigm of warfare that cannot hope to defeat insurgents utilizing postmodern strategies. As the wars in Afghanistan and Iraq have shown beyond reasonable doubt, there is no hope of converting the Middle East to liberalism at the barrel of a gun, just as there was never any hope of Christianizing the Ottoman Empire in the late Middle Ages. In Afghanistan, "Many civilian casualties will be inflicted and the war will go on, but otherwise nothing will happen. Nothing can happen" (Gray 2009:9). In Iraq, the war was lost long ago, probably even before President Bush's "Mission Accomplished" stunt of May 1, 2003, since which time nearly 4,500 American soldiers and more than 110,000 Iraqi civilians have lost their lives in the conflict.

As during the Italian Renaissance, universal spiritual ideals are today subordinated to the self-interest of states. That is not to say that Western states and their populations do not passionately believe in those ideals, simply that state interests come first. Hence, the widespread disenchantment with liberal warfare on 
grounds of hypocrisy: why intervene in East Timor but not Angola, Sierra Leone but not Burundi, Libya but not Bahrain? Clearly, geopolitical interests play a decisive role. At the same time, however, the problem is not simply bad intentions masquerading as good. Allegations of hypocrisy tend to flow from a crude anachronistic Marxism that sees all Western interventions as a mask for imperialism, much as it wrongly regards the early crusades as a pretext for plunder. ${ }^{13}$ This reflects Marxism's general blindness to the importance of religion (The German Ideology notwithstanding). In truth, the primary motivation for contemporary liberal wars, as for medieval crusades, is not economic but cultural: Both types of war are fought to uphold Western ideology. The problem is that, in practice, reasons of state undercut that ideology.

So, when it came to preventing genocide in the Balkans or Rwanda in the 1990s, the West was found hopelessly wanting. Ever since the Jewish Holocaust, there had been an overwhelming consensus in the West that genocide would never be allowed to happen again. Yet when more than 800,000 people lost their lives in Rwanda in 1994, and when the Srebrenica massacre took place on Europe's doorstep in 1995, the West stood strangely paralyzed. "[T]he dithering and the ad hockery, the affectations of cynicism and the placid deceit that so typifies the international behaviour of the great powers in this period" (Bobbitt 2002:7) recall the attitude toward crusade in the 1490s. Universal spiritual ideals (the protection of human rights), coupled with urgent need and the best of intentions, failed to inspire effective coordinated political action. The same could also be said of the Second Congo War (1998-2003), which was allowed to rage unchecked until it became the deadliest conflict since World War II, and the conflict in Darfur (2003-2010), which went on for a further 7 years without decisive intervention. The fraught nature of the interventions in Kosovo and Libya (which drew opposition from Russia and China) and the dubious humanitarian credentials of the US invasion of Iraq in 2003 only speak further to the vitiated conception of liberal warfare.

Contrary to liberals' metaphysical faith in the "emergence" of a global human rights regime, the historical evidence can just as easily be interpreted as pointing in the opposite direction. Realists, for example, argue that the "global legalism" envisioned by liberals is an illusion since international law depends on powerful states to enforce it but that states are locked in incessant rivalry and competition (Bobbitt 2002; Moses 2013). The fact that the United States, China, India, and all Middle Eastern states apart from Jordan refuse to join the International Criminal Court; the presence of notorious human-rights-abusing states on the UN Commission on Human Rights (which had to be reinvented as the UN Human Rights Council) and the passing of the presidency of the Council of Europe to Serbia when it had still not handed over Ratko Mladic; widespread criticism of the various "truth commissions" and International Criminal Tribunals in places like South Africa, the former Yugoslavia, Sierra Leone, and Rwanda for producing lengthy, over-expensive trials that fail to deliver justice; and the West's failure to "put its money where its mouth is" in order to rectify such problems - all

\footnotetext{
${ }^{13}$ The early crusades cleaved to spiritual ideals in their conception if not in their execution, which was notoriously marred by massacres of non-Christians: "Christ was believed to authorize crusades himself-this was one of their characteristic features—and he did so through his chief representative on earth, the pope" (Riley-Smith 1987: xxviii). Legally, the early canonists did their best to place restrictions on the sanctioning of holy war: "A crusade had to be proclaimed by the pope, and there were strict rules governing such proclamations as well as the relationships that obtained among the participating princes" (Bobbitt 2002:78). Bishops, archbishops, and all other clergy did not have the authority to declare a crusade, nor were they allowed to fight in one; instead, command of troops had to be assumed by secular authorities. What motivated the combatants was not power or greed (Christiansen 1980:251; Madden 2002), but the opportunity to pay penitential service through warfare. In that sense, crusade was seen as an act of charity, an opportunity to express love for one's oppressed brothers in a just cause. As Innocent III wrote to the Knights Templar: "You carry out in deeds the words of the Gospel, 'Greater love than this hath no man, that he lay down his life for his friends'."
} 
undermine the idea of a universal regime emerging to prevent human rights abuses. Nor is it clear that such a regime would necessarily offer the best way of achieving that goal in any case: "global civil society [...] has its limitations and can even make things worse where a more traditional, quiet interstate process of diplomacy can produce more dividends" (Armstrong 2010:2134). Aid agencies, for example, can sometimes prolong civil wars by their presence in the affected country.

Although conspiracy theorists see the rise of R2P as legitimating military intervention in America's "War on Terror," 9/11 may actually have been the harbinger of liberal warfare's demise. It was a graphic illustration to liberal states that their own security must come before highfalutin ideals of spreading liberal democracy; however, many successive US administrations have sought to convince us that the two are one and the same. ${ }^{14}$ In that sense, liberal wars suffer the same contradiction as late medieval Christian wars, that is, a fundamental disconnect between the universalizing ideology that motivates them and the particularist interests of the states that actually have to fight them. In the late Middle Ages, the crusading ideal burned out soon after being reignited by the events of the 1490s; it remains to be seen whether or not liberal wars will do the same.

\section{Conclusion}

Conspicuous by its absence in the debate about humanitarian intervention and $\mathrm{R} 2 \mathrm{P}$ has been religion. That debate has been conducted predominantly in the secular language of rights, power, and sovereignty. Yet, liberal warfare is shot through with a theological dimension on account of liberalism's Christian heritage. In this article, I have sought to draw attention to the theology of liberal warfare by treating liberalism as a political religion. This has entailed rejecting both the myth of Western secularism - that the separation of religious and political authority has always been a "defining feature" of Western civilization - and liberalism's claim to be a "secular" ideology that differs from totalitarian ideologies insofar as it keeps religion out of politics. Like communism, National Socialism, and fascism, liberalism is a political religion that inherits certain key assumptions from Christianity-principally a teleological philosophy of history and the belief in an ultimate harmony of truth and value - and, in evangelizing vein, seeks to construct a universal regime in its own image.

It is no accident that with liberalism's ascent as the dominant ideology of Western civilization since 1945 , the medieval just war tradition has made a return in politico-religious form. The concern is much the same as it was in the Middle Ages: to find a way of justifying going to war in order to spread "universal" Western values. Recalling the "two swords" doctrine of the High Middle Ages, liberal wars are not justified through secular/state authority alone, but by the need to uphold those "universal" values. Unlike in the High Middle Ages, however, actually mobilizing effective military operations on the basis of "universal" values proves fraught with difficulties. In this, contemporary liberal warfare finds its precursor, not in high medieval crusades, but in late medieval Christian warfare when the crusading ideal had been rendered hopelessly anachronistic by developments in early modern statecraft.

I have sought to bring out the affinities between today's liberal wars and late medieval Christian warfare by sketching an analogy between the hackneyed millenarian interpretations of history in both eras, the disturbing implications of

\footnotetext{
${ }^{14}$ In the words of Rice (2008), "we do not really accept that our national interest and our universal ideals are at odds." In 2011, Obama told the British House of Commons: "We reject as false the choice between our interests and our ideals; between stability and democracy."
} 
such interpretations for war in the Middle East, and the wildly unrealistic expectations of Western ideologues that a (post-Augustinian) theological ideal might be realized here on earth in the form of an "emergent" universal regime on the Western model. ${ }^{15}$ Liberal wars are not crusades, nor are they attempts to resurrect traditional wars of religion. They are something even worse: distant echoes of a late medieval age whose wars in defense of the faith were already washed up remnants of crusades from centuries past.

We would do well to remember Gray's dictum, "Politics is the art of devising temporary remedies for recurring evils - a series of expedients, not a project of salvation" (2009:3). In the early modern period, the papacy's "two swords" doctrine stoked the wars of religion between Catholics and Protestants as Rome's claims to universal jurisdiction were ultimately rejected by dissenters who saw fit to practice their faith in their own way. Let us hope that no such politico-religious conflagration awaits us in the twenty-first century, replete with weapons of mass destruction, as states choose to pursue their own brand of liberalism (or alternative ideology) instead of falling into line with America's universal regime.

\section{References}

Achcar, Gilbert. (2002) The Clash of the Barbarisms: The Making of the New World Disorder, trans. Peter F. Drucker. New York: Monthly Review Press.

Agrama, Hussein Ali. (2010) Secularism, Sovereignty, Indeterminacy: Is Egypt a Secular or a Religious State? Comparative Studies in Society and History 52(3): 495-523.

Annan, Kofi. (1999) "Two Concepts of Sovereignty". The Economist 352 (16 September). Available at http://www.economist.com/node/324795 (Accessed July 9, 2013.)

Armstrong, David. (2010) Evolving Conceptions of Justice in International Law. Review of International Studies 37(5): 2126-2136.

Bacevich, Andrew. (2002) American Empire: The Realities and Consequences of U.S. Diplomacy. Cambridge, MA: Harvard University Press.

Barkawi, Tarak. (2010) State and Armed Force in International Context. In Mercenaries, Pirates, Bandits and Empires, edited by Alejandro Colas and Bryan Mabee. London: Hurst, 33-53.

Bellah, Robert. (1967) Civil Religion in America. Daedalus 96(1): 1-21.

Bellamy, Alex. (2008) The Responsibility to Protect and the Problem of Military Intervention. International Affairs 84(4): 615-639.

Bobbitt, Philip. (2002) The Shield of Achilles: War, Peace, and the Course of History. London: Penguin.

Bush, George W. (2002) West Point Commencement. 1 June. Available at http:// georgewbush-whitehouse.archives.gov/infocus/bushrecord/documents/Selected_Speeches_ George_W_Bush.pdf. (Accessed July 9, 2013.)

Cavanaugh, William. (1995) A Fire Strong Enough to Consume the House: The Wars of Religion and the Rise of the State. Modern Theology 11(4): 397-420.

Chambers, David. (2006) Popes, Cardinals and War: The Military Church in Renaissance and Early Modern Europe. London and New York: I. B. Tauris.

Christiansen, Eric. (1980) The Northern Crusades: The Baltic and the Catholic Frontier, 1100-1525. London: Macmillan.

Cohen, Gidon. (2010) Political Religion and British Communism. 20th Century Communism 2: 197214.

Columbus, Christopher. (1988) The Diario of Christopher Columbus's First Voyage to America, 14921493, trans. Oliver Dunn and James E. Kelley. Norman, OK: University of Oklahoma Press.

Cunliffe, Philip. (2006) Sovereignty and the Politics of Responsibility. In Politics Without Sovereignty: A Critique of Contemporary International Relations, edited by Christopher Bickerton, Philip Cunliffe, and Alexander Gourevitch. Oxford: University College London Press.

\footnotetext{
${ }^{15}$ Edward Luck is somewhat disingenuous when he claims: "RtoP [...] was really a southern concept with strong African roots. Well before the 2001 ICISS report, both the Economic Community of West African States and the African Union (AU) had voiced similar principles" (Luck 2009:38). In truth, the ICISS report, which coined "R2P," was $50 \%$ chaired by a Westerner: the former Australian foreign minister, Gareth Evans. Moreover, R2P is a product of Western liberalism and its "roots" reach back to Western Christianity. If "southern" states invoke R2P, they do not originate the term but, rather, appropriate it for their own political ends.
} 
Dallmayr, Fred. (2012) Post-Secularity and (Global) Politics: A Need for Radical Redefinition. Review of International Studies 38(5): 963-973.

Deng, Francis M., I. Sadikiel Kimaro, William Zartmann, Donald Rothchild, and Terrence Lyons. (1996) Sovereignty as Responsibility: Conflict Management in Africa. Washington, DC: Brookings Institution.

Desch, Michael. (2010) The More Things Change, the More They Stay the Same: The Liberal Tradition and Obama's Counterterrorism Policy. PS, Political Science EF Politics 43(3): 425-429.

Deudney, Daniel, and G. John Ikenberry. (1999) The Nature and Sources of Liberal International Order. Review of International Studies 25(2): 179-196.

Doyle, Michael. (2011) International Ethics and the Responsibility to Protect. International Studies Review 13: 72-84.

Drezner, Daniel. (2009) The New New World Order. In Global Politics in a Changing World, edited by Richard Mansbach and Edward Rhodes. Boston, MA: Houghton Mifflin.

Egerton, George W. (1983) Collective Security as Political Myth: Liberal Internationalism and the League of Nations in Politics and History. International History Review 5(4): 496-524.

Evans, Gareth. (2008) The Responsibility to Protect: Ending Mass Atrocity Crimes Once and for All. Washington, DC: Brookings Institution Press.

Fortier, Jeremy (2010) Can Liberalism Lose The Enlightenment? Journal of Politics 72(4): 10031013.

France, John. (2005) The Crusades and the Expansion of Catholic Christendom, 1000-1714. London and New York: Routledge.

Freedman, Lawrence. (2005) Force and Legitimacy in World Politics. Review of International Studies 31: 93-107.

Fukuyama, Francis. (1989) The End of History? The National Interest 16(4): 3-18.

Funuyama, Francis. (1992) The End of History and the Last Man. London/New York: Penguin.

Funuyama, Francis. (1995) Reflections on the End of History, Five Years Later. History and Theory 34 (2): 27-43.

Geertz, Clifford. (1973/1993) The Interpenetration of Cultures. London: Fontana.

Gentile, Emilio. (2006) Politics as Religion. Princeton: Princeton University Press.

Gray, John. (2009) Gray's Anatomy. London: Penguin.

Griffin, Roger. (2005) God's Counterfeiters? Investigating the Triad of Fascism, Totalitarianism and (Political) Religion. In Fascism, Totalitarianism and Political Religion, edited by Roger Griffin. Abingdon: Routledge.

Habermas, Jürgen. (2010) An Awareness of What Is Missing, trans. Ciaran Cronin. Cambridge: Polity.

Hall, Rodney Bruce. (1999) National Collective Identity: Social Constructs and International Systems. New York: Columbia University Press.

Hehir, J. Bryan. (1992) Just War Theory in a Post-Cold War World. Journal of Religious Ethics 20(2): 237-257.

Hirschindnd, Charles. (2008) Religious Difference and Democratic Pluralism: Some Recent Debates and Frameworks. Temenos 44(1): 67-82.

Hodges, Adam, and Chad Nilep, Eds. (2007) Discourse, War, and Terrorism. Amsterdam and Philadelphia: John Benjamins Publishing Company.

Huntington, SAMuel. (1996) The Clash of Civilizations and the Remaking of World Order. London: Simon and Schuster.

International Commission on Intervention and State Sovereignty. (2001) The Responsibility to Protect. Ottawa: The International Development Research Centre.

Johnson, James T. (2003) Aquinas and Luther on War and Peace: Sovereign Authority and the Use of Armed Force. Journal of Religious Ethics 31 (1): 3-20.

Johnson, Marion. (1981) The Borgias. London: Penguin.

Jouannet, Emmanuelle. (2007) Universalism and Imperialism: The True-False Paradox of International Law? European Journal of International Relations 18: 379-407.

Juergensmeyer, Mark. (2008) Global Rebellion: Religious Challenges to the Secular State, from Christian Militias to al Qaeda. Berkeley and Los Angeles: University of California Press.

Kaempf, Sebastian. (2009) Double Standards in US Warfare: Exploring the Historical Legacy of Civilian Protection and the Complex Nature of the Moral-Legal Nexus. Review of International Studies 35: 651-674.

Kant, Immanuel. (2010/1795) Perpetual Peace: A Philosophical Essay. New York: Cosimo.

Keen, Maurice. (2005) Chivalry. New Haven: Yale University Press.

Luck, Edward C. (2009) Environmental Emergencies and the Responsibility to Protect: A Bridge Too Far? Proceedings of the Annual Meeting of the American Society of International Law 103: 32-38. 
Madden, Thomas. (2002) "The Real History of the Crusades." Crisis Magazine. Available at http:// www.crisismagazine.com/2011/the-real-history-of-the-crusades. (Accessed July 9, 2013.)

Mavelli, Luca, and Fabio Petito. (2012) The Postsecular in International Relations: An Overview. Review of International Studies 38(5): 931-942.

Moses, Jeremy (2013) Sovereignty as Irresponsibility? A Realist Critique of the Responsibility to Protect. Review of International Studies 39(1): 113-135.

Poeschel, Sabine. (1988) Alexander Magnus Maximus-neue Aspekte zur Ikonographie Alexanders des Grossen im Quattrocento. Römisches Jahrbuch für Kunstgeschichte 23-24: 62-74.

Rawls, John (1993) Political Liberalism. New York: Columbia University Press.

Reus-Smit, Christian. (1999) The Moral Purpose of the State. Princeton, NJ: Princeton University Press.

Rice, Condoleeza. (2008) Rethinking the National Interest: American Realism for a New World. Foreign Affairs 87: 2-26.

Riley-Smith, Jonathan. (2005/1987) The Crusades: A History. London: Continuum.

Schmitt, Carl. (2005/1922) Political Theology: Four Chapters on the Concept of Sovereignty, trans. George Schwab. Chicago: University of Chicago Press.

Scruton, Roger. (2002) The West and the Rest. London: ISI Books.

Setton, Kenneth. (1978) The Papacy and the Levant: 1204-1571. Philadelphia: American Philosophical Society.

Shakman Hurd, Elizabeth. (2012) International Politics After Secularism. Review of International Studies 385: 943-961.

Shklar, Judith N. (1991) Redeeming American Political Theory. American Political Science Review 85 (1): $3-15$.

SNyder, Jack, Ed. (2011) Religion and International Relations Theory. New York: Columbia University Press.

Stahn, Carsten. (2007) Responsibility to Protect: Political Rhetoric or Emerging Legal Norm? The American Journal of International Law 101 (1): 99-120.

Stiglitz, JosePh. (2002) Globalization and Its Discontents. London: Penguin.

Stinger, Charles. (1998) The Renaissance in Rome. Bloomington, IN: Indiana University Press.

Walker, Thomas. (2008) Two Faces of Liberalism: Kant, Paine, and the Question of Intervention. International Studies Quarterly 52: 449-468. 